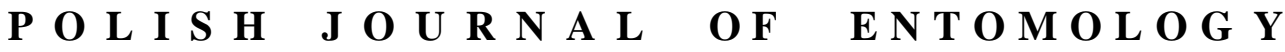

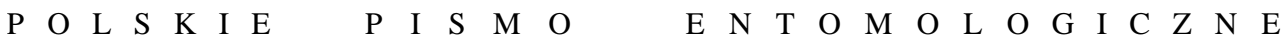

VOL. 85: 377-388

Lublin

31 December 2016

DOI: $10.1515 /$ pjen-2016-0022

\section{Efficacy of aqueous extracts of black alder (Alnus glutinosa GAERTN.) and black elderberry (Sambucus nigra L.) in reducing the occurrence of Phyllotreta spp., some lepidopteran pests and diamondback moth parasitoids on white cabbage}

\author{
BEATA JANKOWSKA*, ELŻBIETA WOJCIECHOWICZ-ŻYTKO
}

Department of Plant Protection, Faculty of Biotechnology and Horticulture, Kraków University of Agriculture, 29 Listopada 54, 31-425 Kraków, Poland

\begin{abstract}
The insecticidal and antifeedant effects of aqueous extracts from two common plants (black alder Alnus glutinosa and black elderberry Sambucus nigra) on the occurrence of flea beetles (Phyllotreta spp.), as well as lepidopteran pests like the diamondback moth Plutella xylostella, small white butterfly Pieris rapae, large white butterfly Pieris brassicae, cabbage moth Mamestra brassicae and the Plutella xylostella parasitoid complex were investigated on white cabbage in 2008-2009. Aqueous extracts of black elderberry Sambucus nigra significantly reduced numbers of flea beetles Phyllotreta spp., eggs of Pieris rapae and P. brassicae, and larvae and pupae of Plutella xylostella on the cabbage. The aqueous extract of Alnus glutinosa was less effective. Parasitoids had the greatest impact on reducing numbers of diamondback moth: the dominant species was Diadegma fenestralis. The smallest number of parasitoids was reared from pupae collected from plots where the cabbages had been sprayed with the Sambucus nigra extract.
\end{abstract}

KEY WORDS: botanical insecticides, flea beetles, Pieris spp., Mamestra brassicae, Plutella xylostella.

\section{INTRODUCTION}

White cabbage is one of the economically most important vegetables in Poland. During their growth, cabbage crops are attacked by a large number of insect pests (SzWEJDA 2004, JANKOWSKA et al. 2011), including a number of lepidopteran species. The most serious

\footnotetext{
*Corresponding author: jankowskab@ogr.ar.krakow.pl
} 
damage is caused by caterpillars of the small white butterfly (Pieris rapae LINNAEUS, 1758), the large white butterfly (Pieris brassicae LinNAEUs, 1758), the cabbage moth (Mamestra brassicae LINNAEUS, 1758) and the diamondback moth (Plutella xylostella LINNAEUS, 1758) (JANKOWSKA 2005, 2006). The widespread use of chemical insecticides has brought about irreversible changes in biocenoses and lowered the quality of agricultural products. This is why interest in applying natural substances for protecting plants against pests is increasing. Plants are the richest source of renewable natural pesticides. Specifically, plant extracts offer a safe and viable alternative to synthetic pesticides and are compatible with the use of beneficial organisms, pest-resistant plants, and to preserving a healthy environment in an effort to decrease reliance on synthetic compounds. The benefits of using botanical pesticides are many: reduced environmental degradation, enhanced food safety, reduced resistance to pesticides, and improved profitability of production (ENDERSBY \& MORGAN 1991).

Plants consist of chemical substances, not all of which are directly beneficial for their growth and development. These secondary compounds affect insects by acting as repellents, antifeedants, toxins, or deterrents to feeding or oviposition; they may also have an antibacterial and fungistatic impact (NAWROT 1984, BURGIEE 2005). Much scientific interest has focused on plant-derived products, and already more than 2000 plant species are known to have insecticidal properties (KLOCKE 1989). Many authors have pointed out the antifeedant activity of plant extracts in relation to phytophages associated with cabbage (ENDERSBY \& MORGAN 1991). The purpose of the present study was therefore to test aqueous extracts of two wild plants - black alder Alnus glutinosa GAERTN. and black elderberry Sambucus nigra L. - for their antifeedant properties and toxic effects on retarding the development and reducing the occurrence of pest insects on white cabbage under field conditions. The cabbage aphid Brevicoryne brassicae LINNAEUS, 1758 has been dealt with in detail elsewhere (JANKOWSKA \& WOJCIECHOWICZ-ŻYTKO 2016). This paper presents the results of field studies on the occurrence of flea beetles and lepidopteran pests such as the diamondback moth (DBM) Plutella xylostella, small white butterfly Pieris rapae, large white butterfly Pieris brassicae and cabbage moth Mamestra brassicae. A further aim of this work was to determine the impact of aqueous plant extracts on the presence of the P. xylostella parasitoid complex.

\section{Funding}

This research was supported by the Ministry of Science and Higher Education of Poland as part of the statutory activities of Department of Plant Protection, University of Agriculture, DS-3500/WBiO/. 


\section{MATERIALS AND METHODS}

The research was carried out at an organic farm in Roczyny near Andrychów (in 2008) and at the Experimental Station of the Plant Protection Department of the University of Agriculture in Mydlniki near Kraków (in 2009) on typical brown soil (III a). Two white cabbage cultivars were tested in the experiment: 'Kamienna Głowa' in 2008 and 'Amager' in 2009. The experimental combinations were as follows: A - unsprayed cabbage (control), B - cabbage sprayed with Alnus glutinosa extract, C - cabbage sprayed with Sambucus nigra extract. On each plot $\left(12 \mathrm{~m}^{2}-6 \mathrm{~m}\right.$ long x $2 \mathrm{~m}$ wide) 75 plants were transplanted at a spacing of $40 \times 50 \mathrm{~cm}$ in late May. No chemical treatments were applied on any of the plots and weeds were removed mechanically. To prepare the extracts, young, healthy leaves were harvested from alder/elderberry trees growing in their natural habitats and then dried in a ventilated room without access to sunlight. The extracts were made by steeping $50 \mathrm{~g}$ of ground, dried leaves in $100 \mathrm{ml}$ water for 24 hours (WAWRZYNIAK 1996a) and thereafter filtering through muslin. Plants were sprayed once a week in the evening. Fifteen plants growing in the central part of each plot ( 3 replicates of 5 plants each) were selected for analysis and marked. The analyses were carried out once a week, 1-2 days after spraying. Each time, the numbers of flea beetles, eggs and larvae of the small and large white butterflies, the cabbage moth and DBM larvae/pupae were counted on the plants. The DBM pupae were stored separately in glass vials in the laboratory until either parasitoids or moths emerged. The emerged parasitoid adults were identified to species level based on the key by MICZULSKI (2007) and the 'key to determining the parasitoids reared from caterpillars and pupae of the diamondback moth' by KAŁMUK (2004). The Duncan multiple test $(\alpha=0.05)$ was used for the statistical workup of the results.

\section{RESULTS}

During the study two flea beetle species - Phyllotreta nemorum LINANEUs, 1758 and $P$. atra (FABRICIUS, 1775) - were identified; the former was dominant. In both years there were fewer beetles on sprayed than on unsprayed cabbage, but the difference in both years was significant only in the case of the Sambucus nigra extract (Table 1). Moreover, the efficacy of treatment differed depending on the extract: spraying cabbage with Alnus glutinosa and Sambucus nigra extracts reduced beetle numbers by $15.7 \%$ and $53.9 \%$ respectively in 2008 and by $41.8 \%$ and $78 \%$ respectively in 2009 (Table 2). 
Table 1. The occurrence of certain pests on cabbage plants treated and untreated with plant extracts (2008-2009); A - unsprayed cabbage (control), B - cabbage sprayed with Alnus glutinosa extract, C - cabbage sprayed with Sambucus nigra extract.

\begin{tabular}{|c|c|c|c|}
\hline Species of pest & A & B & $\mathbf{C}$ \\
\hline \multicolumn{4}{|c|}{ Mean number per plant in 2008} \\
\hline $\begin{array}{l}\text { Phyllotreta spp. } \\
\text { adults }\end{array}$ & $1.15 \mathrm{~b}$ & $0.97 \mathrm{~b}$ & $0.59 \mathrm{a}$ \\
\hline $\begin{array}{l}\text { Plutella xylostella } \\
\text { larvae and pupae }\end{array}$ & $0.80 \mathrm{~b}$ & $0.72 \mathrm{~b}$ & $0.50 \mathrm{a}$ \\
\hline $\begin{array}{l}\text { Pieris rapae } \\
\text { eggs } \\
\text { caterpillars }\end{array}$ & $\begin{array}{l}0.40 \mathrm{~b} \\
0.30 \mathrm{~b}\end{array}$ & $\begin{array}{l}0.30 \mathrm{~b} \\
0.20 \mathrm{~b}\end{array}$ & $\begin{array}{l}0.20 \mathrm{a} \\
0.10 \mathrm{a}\end{array}$ \\
\hline $\begin{array}{l}\text { Pieris brassicae } \\
\text { eggs } \\
\text { caterpillars }\end{array}$ & $\begin{array}{l}0.42 \mathrm{~b} \\
0.04 \mathrm{c}\end{array}$ & $\begin{array}{l}0.33 \mathrm{~b} \\
0.24 \mathrm{~b} \\
\end{array}$ & $\begin{array}{l}0.20 \mathrm{a} \\
0.13 \mathrm{a} \\
\end{array}$ \\
\hline $\begin{array}{l}\text { Mamestra brassicae } \\
\text { eggs } \\
\text { caterpillars }\end{array}$ & $\begin{array}{l}0.42 \mathrm{a} \\
0.00\end{array}$ & $\begin{array}{l}0.30 \mathrm{a} \\
0.00\end{array}$ & $\begin{array}{l}0.40 \mathrm{a} \\
0.00\end{array}$ \\
\hline \multicolumn{4}{|c|}{ Mean number per plant in 2009} \\
\hline $\begin{array}{l}\text { Phyllotreta spp. } \\
\text { adults }\end{array}$ & $2.75 \mathrm{~b}$ & $1.60 \mathrm{~b}$ & $0.58 \mathrm{a}$ \\
\hline $\begin{array}{l}\text { Plutella xylostella } \\
\text { larvae and pupae }\end{array}$ & $0.22 \mathrm{~b}$ & $0.17 \mathrm{~b}$ & $0.05 \mathrm{a}$ \\
\hline $\begin{array}{l}\text { Pieris rapae } \\
\text { eggs } \\
\text { caterpillars }\end{array}$ & $\begin{array}{l}0.42 \mathrm{~b} \\
0.01 \mathrm{~b}\end{array}$ & $\begin{array}{l}0.34 \mathrm{~b} \\
0.01 \mathrm{~b}\end{array}$ & $\begin{array}{l}0.20 \mathrm{a} \\
0.00 \mathrm{a}\end{array}$ \\
\hline
\end{tabular}

The mean numbers identified in the rows with the same letters do not differ significantly $(\alpha=0.05)$.

Table 2. Reduction in pest numbers (\%) depending on the protection methods applied (2008-2009); B - cabbage sprayed with Alnus glutinosa extract, C - cabbage sprayed with Sambucus nigra extract.

\begin{tabular}{|l|c|c|}
\hline \multirow{2}{*}{ Species } & \multicolumn{2}{c|}{ Pest reduction (\%) } \\
\cline { 2 - 3 } & B & C \\
\hline \multicolumn{2}{|c|}{2008} & 53.9 \\
\hline Phyllotreta spp. (beetles) & 15.7 & 37.5 \\
\hline Plutella xylostella (larvae and pupae) & 10.0 & 50.0 \\
\hline Pieris rapae - eggs & 15.0 & 52.4 \\
\hline Pieris brassicae - egg clutches & 21.4 & 4.8 \\
\hline Mamestra brassicae - eggs & 5.0 & 78.0 \\
\hline \multicolumn{2}{|c|}{} & 77.3 \\
\hline Phyllotreta spp. (beetles) & 41.8 & 50.0 \\
\hline Plutella xylostella (larvae and pupae) & 22.7 & \\
\hline Pieris rapae - eggs & 15.0 & \\
\hline
\end{tabular}


In 2008-2009 eggs and caterpillars of some lepidopteran pests - small white butterfly, large white butterfly, cabbage moth and diamondback moth - were observed on cabbage leaves. Fewer eggs were laid by Pieris rapae and P. brassicae on the treated plants, but the Sambucus nigra extract proved to be more effective in this respect (Tables 1,2). Spraying had no significant effect on oviposition by the cabbage moth (Table 1).

In the case of DBM only the Sambucus nigra extract reduced its numbers to a significant extent. On plants treated with this extract, there were significantly fewer DMB larvae and pupae than on the control plots and the plots treated with Alnus glutinosa extracts (Table 1). Parasitoids had the greatest impact on reducing DBM numbers. The results of rearing pupae of this pest are shown in Table 3. Total parasitization of DBM varied from 60 to $72 \%$, depending on the experimental combination (Table 4). 54 specimens of parasitic wasps belonging to 6 species from the families Ichneumonidae ( 3 species), Braconidae (2 species) and Pteromalidae (1 species) emerged from the collected DBM pupae. The species composition and numbers of parasitoids are listed in Table 3 and 4. The most abundant of the DBM parasitoid species was Diadegma fenestralis (HOLMGREN, 1860). (70.4\% of all the wasps reared). The next most numerous parasitoid (14.8\%) was Diadromus collaris (GRAVENHORST, 1829) (Table 3). The smallest number of parasitoids was reared from pupae collected from the plot where the cabbages were sprayed with the Sambucus nigra extract (Table 4).

Table 3. Parasitoids emerged from pupae of the diamondback moth (Plutella xylostella) collected from white cabbage in 2009 (total from all combinations).

\begin{tabular}{|c|c|c|c|c|}
\hline \multirow[t]{2}{*}{ Species } & \multicolumn{2}{|c|}{2009} & \multirow[t]{2}{*}{ Class } & \multirow[t]{2}{*}{ Type of parasitization } \\
\hline & No. & $\%$ & & \\
\hline \multicolumn{5}{|c|}{ Ichneumonidae } \\
\hline Diadegma fenestralis & 38 & 70.40 & ED & parasitoid of caterpillars \\
\hline Diadromus collaris & 8 & 14.80 & ED & parasite of pupae \\
\hline Mesochorus sp. & 1 & 1.850 & $\mathrm{R}$ & hyperparasitoid \\
\hline \multicolumn{5}{|c|}{ Braconidae } \\
\hline $\begin{array}{l}\text { Cotesia longipalpis } \\
\text { REINHARD, } 1880\end{array}$ & 2 & 3.70 & SD & parasitoid of caterpillars \\
\hline $\begin{array}{l}\text { Cotesia fuliginosus } \\
\text { (WESMAEL, 1837) }\end{array}$ & 4 & 7.40 & $\mathrm{D}$ & parasitoid of caterpillars \\
\hline \multicolumn{5}{|c|}{ Pteromalidae } \\
\hline Habrocytus sp. & 1 & 1.85 & $\mathrm{R}$ & hyperparasitoid \\
\hline Total & 54 & 100.00 & - & - \\
\hline
\end{tabular}


Table 4. Species composition and number of parasitoids of diamondback moth Plutella xylostella on white cabbage in different combinations in 2009; A - unsprayed cabbage (control), B - cabbage sprayed with Alnus glutinosa extract, C - cabbage sprayed with Sambucus nigra extract.

\begin{tabular}{|l|c|c|c|}
\hline \multirow{2}{*}{ Parasitoids species } & \multicolumn{3}{|c|}{ Combination } \\
\cline { 2 - 4 } & A & B & C \\
\hline Diadegma fenestralis & 25 & 9 & 4 \\
\hline Diadromus collaris & 4 & 3 & - \\
\hline Mesochorus sp. & 1 & - & - \\
\hline Cotesia longipalpis & 1 & 1 & - \\
\hline Cotesia fuliginosus & 2 & 2 & $5 \mathrm{a}$ \\
\hline Habrocytus sp. & 1 & - & $60 \mathrm{a}$ \\
\hline Total & $34 \mathrm{~b}$ & $15 \mathrm{a}$ & $65 \mathrm{ab}$ \\
\hline Parasitization $\%$ & $72 \mathrm{~b}$ & $\mathrm{~b}$ & \\
\hline
\end{tabular}

The mean numbers identified in the rows with the same letters do not differ significantly $(\alpha=0.05)$.

\section{DISCUSSION}

Adults of Phyllotreta CHEVROLAT, 1836 beetles chew out small circular holes or pits in the leaf tissue and may cause plant stunting or death when they occur in large numbers on young plants, although they usually do not cause economic damage on older plants. The stimulant for feeding behaviour in cabbage flea beetles is allyl isothiocyanate (BENEDEK et al. 2005, TÓTH et al. 2007). TAHVANAINEN \& ROOT (1972) used the highly odorous ragweed (Ambrosia artemisifolia L.) to repel the flea beetle Phyllotreta cruciferae (GoEZE, 1777) from a collard crop. PALANISWAMY \& WIZE (1994) noted that a neem extract significantly reduced the numbers and feeding activity of crucifer flea beetles. In previous studies, JANKOWSKA (2008) reduced numbers of flea beetles with aqueous extracts of Tagetes L., and JANKOWSKA \& WILK (2011) reduced numbers of flea beetles with aqueous extracts of Calendula officinalis L. and Euphorbia cyparissias L..

Botanical insecticides can influence the behaviour and development of herbivorous insects searching a plant for a suitable oviposition site. Host specificity in oligophagous herbivorous insects is due to gravid females showing discrimination in their choice of plant on which to oviposit. Female lepidopterans perform exploratory runs over the leaves of potential host plants and, when stimulated, lay their eggs on the leaves. Lepidopteran pests of Brassicaceae, like Plutella xylostella and Pieris spp. use glucosinolates as oviposition stimulants (VAN LOON et al. 1992, PIVNICK et al. 1994, 1999, FAHEY et al. 2001, HAMILTON et al 2005). Moreover, SHU-SHENG et al. (2005) highlight the fact that the acceptance or rejection of a particular plant by females is regulated not only by the presence or absence of oviposition stimulants, but by negative stimuli evoked by co-occurring deterrents. In the 
behavioural control of pest insects, chemicals derived from non-host plants applied to crops are expected to repel searching adults and thereby reduce egg laying. The spraying of cabbage with the extracts of other plants, may also mask their proper scent and can make it difficult for pests to find them.

Extracts of Sambucus nigra proved to be the most effective at repelling searching adults, and thus reducing oviposition. Most parts of $S$. nigra, but particularly the leaves, are thought to contain various cyanogenic glycosides and to be somewhat toxic (ATKINSON \& ATKINSON 2002). WASINA (1987) stated that an alder extract was effective in reducing Lymantria dispar (LINNAEUS, 1758) caterpillars feeding on oak leaves; our research, however, showed that the efficacy of the aqueous Alnus glutinosa extract was worse. JANKOWSKA (2012) noted that spraying white cabbage with plant extracts (calendula, coriander, Chrysanthemum carinatum SCHOUSB.) significantly reduced the numbers of lepidopteran eggs laid on white cabbage, and that their use did not adversely affect the occurrence of beneficial insects. Also, her earlier studies had shown that spraying cabbage with extracts of Tagetes, Calendula L. and Euphorbia cyparissias could significantly reduce the numbers of eggs laid by Pieris rapae and could afford complete protection of plants against oviposition by P. brassicae and Mamestra brassicae (JANKOWSKA 2008, JANKOWSKA \& WILK 2011). In a study of the aqueous extracts of 28 plants from the families Apiaceae, Polygonaceae, Rutaceae, Solanaceae and Asteraceae for their actions with respect to Pieris brassicae, WAWRZYNIAK (1996a) observed that in the field, such extracts of coriander and marigold protect the plant from eggs being laid on them and in the case of marigold also rendered unviable a large number of the eggs already present on the plant. In other studies WAWRZYNIAK $(1994,2000,2009)$ showed that aqueous extracts of a great many plants protect cabbage plants in the field before egg deposition. These studies also showed that the use of extracts had no negative impact on the parasitoid Cotesia glomerata (LINNAEUS, 1758), the development of only a few of which was inhibited (WAWRZYNIAK 1996c, 1997). In the literature there is also information on the use of plant extracts to reduce the number of Plutella xylostella. (TABASHNIK 1985, 1987) stated that the application of coumarin or rutin to cabbage leaves prevent $P$. xylostella and Pieris rapae from laying eggs on them. SHU-SHENG et al. (2005) noted that coating leaves with an extract of Chrysanthemum morifolium RAMAT. discouraged DBM females from laying eggs. ChARLESTON et al. (2005b) observed significantly fewer eggs on leaves treated with an extract of Melia azedarach L. DADANG \& OHSAWA (2001), using extracts of Alpinia galanga WILLD. and Gomphrena globose L., reduced the number of feeding caterpillars more effectively than with the use of the insecticide Decis 72 EC. DADANG et al. (2008) achieved better results using a mixture of plant extracts than with synthetic pyrethroids. JANKOWSKA $(2008,2012)$ and JANKOWSKA \& WILK (2011), who sprayed cabbages with 
extracts of Tagetes, Calendula, Euphorbia cyparissias, coriander and Chrysanthemum carinatum, obtained a significant reduction in the numbers of Plutella xylostella.

The same signals that attract herbivorous insects are also attractive to predators and parasitoids (HARAMATHA \& NAWROT 1985, KARIMZAHED \& WRIGHT 2008). Parasitoids had the greatest impact on reducing the number of DBMs: the dominant species was Diadegma fenestralis (HoLmgren, 1860). In Poland, LAGOWSKA (1981) found D. fenestralis to be the dominant species, reducing the pest population by $40-90 \%$. Further observations of the dominant parasitoid species $D$. fenestralis were made by WIECH \& JANKOWSKA (1999), WIECH \& KAŁMUK $(2002,2003)$, JANKOWSKA \& WIECH (2006), JANKOWSKA \& WILK (2011), JANKOWSKA (2012). JANKOWSKA (2012) noted that the use of plant extracts did not adversely affect the occurrence of DMB parasitoids; indeed, some caterpillars preferentially fed on the extract-treated plants because they found them more attractive. SHU-SHENG et al. $(2005,2006)$ to diccourage of DMB female from laying eggs on plants, sprayed them with extract of Chrysanthemum morifolium. Authors found out that DMB caterpillars feeding on the treated leaves were more attractive for parasitoid Cotesia plutellae (KURDJUMOV, 1912). CHARLESTON et al. (200a), who studied the effect of botanical insecticide derived from the syringa tree, Melia azedarach and the neem tree, Azadirachta indica A.Juss. found that these preparations did not have a negative impact on DBM parasitoids (Diadromus collaris and Cotesia plutellae) and in the glasshouse a significantly higher proportion of Plutella xylostella were parasitised by Cotesia plutellae on plants treated with botanical pesticides than on the control plants.

Deterrent properties are important factors in pest control and the application of plant extracts did not adversely affect the occurrence of beneficial insects. Some of the parasites and predators occur naturally, so conservation of these existing natural enemies can be extremely important in suppressing pest populations. The results of this study indicate that botanical insecticides from Sambucus nigra have the potential to be incorporated into control programmes for cabbage pests.

\section{CONCLUSIONS}

1. Aqueous extracts of black elderberry Sambucus nigra significantly reduced the number of flea beetles Phyllotreta spp, eggs of Pieris rapae and P. brassicae and larvae and pupae of Plutella xylostella on plants.

2. Spraying the extracts had no significant effect on oviposition by the cabbage moth Mamestra brassicae.

3. Parasitoids had the greatest impact on reducing the number of diamondback moths: the dominant species was Diadegma fenestralis. 
4. The smallest number of parasitoids was reared from pupae collected from the plot where the cabbages had been sprayed with the Sambucus nigra extract.

\section{REFERENCES}

AtKINSON M.D., ATKINSON E. 2002. Sambucus nigra L. Journal of Ecology 90(5): 895-923.

Beneder P., BaKCSa F., Tóth M., Csonka É. 2005. Allyl isothiocyanate baited traps to monitor cabbage flea beetles (Phyllotretra spp., Coleoptera: Chrysomelidae). International Journal of Horticultural Science 11(1): 95-99.

BURGIEŁ Z. 2005. Can plant preparations replace synthetic pesticides? [in:] K. WIECH, H. KoŁOCZEK, P. KASZYCKI (eds). Protection of the environment in the $21^{\text {st }}$ century - new challenges and threats. Fundacja na Rzecz Wspierania Badań Naukowych Wydziału Ogrodniczego Akademii Rolniczej im. Hugona Kołłątaja w Krakowie, Kraków, 116-125. (in Polish)

Charleston D.S., KFir R., Dicke M., Vet L.E.M. 2005a. Impact of botanical pesticides derived from Melia azedarach and Azadirachta indica on the biology of two parasitoid species of the diamondback moth. Biological Control 33(2): 131-142.

Charleston D.S., KfiR R., Vet L.E.M., Dicke M. 2005b. Behavioural response of diamondback moth Plutella xylostella (Lepidoptera: Plutellidae) to extracts derived from Melia azedarach and Azadirachta indica. Bulletin of Entomological Research 95(5): 457-465.

Dadang S., Andriani L., Ohsawa K. 2008. Compatibility of Annonaceae and Meliaceae plant extract mixtures in causing mortality effect against the cabbage head caterpillar, Crocidolomia pavonana (F.) (Lepidoptera: Pyralidae) larvae. Journal of the International Society for South Asian Agricultural Sciences 13(3): 1-16.

DADANG L., OHSAWA K. 2001. Efficacy of plant extracts for reducing larval population of the diamondback moth, Plutella xylostella L. (Lepidoptera: Yponomeutidae) and cabbage webworm, Crocidolomia binotalis ZelLeR (Lepidoptera: Pyralidae) and evaluation of cabbage damage. Applied Entomology and Zoology 36(1): 143-149.

ENDERSBy N.M., MoRgan W.C. 1991. Alternatives to Synthetic Chemical Insecticides for Use in Crucifer Crops. Biological Agriculture and Horticulture 8(1): 33-52.

Fahey J.W., Zalcmann A.T., Talalay P. 2001. The chemical diversity and distribution of glucosinolates and isothiocyanates among plants.Phytochemistry 56(1): 5-51.

Hamilton A.J., Endersby N.M., Ridland P.M., Zhang J., Neal M. 2005. Effects of cultivar on oviposition preference, larval feeding and development time of diamondback moth, Plutella xylostella (L.) (Lepidoptera: Plutellidae), on some Brassica oleracea vegetables in Victoria. Australian Journal of Entomology 44(3): 284-287.

HARAmATHA J., NAwROT J. 1985. The plant substances that affect the development and behavior of insects. [in:] Materials of the $25^{\text {th }}$ Scientifoc Session of the Institute of Plant Protection. Instytut Ochrony Roślin, Poznań, 141-151. (in Polish)

JANKOWSKA B. 2005. The comparison of the occurrence of the diamondback moth Plutella xylostella L. (Lepidoptera, Plutellidae) on the different cabbage vegetables. Vegetable Crops Research Bulletin 62: 153-163. 
JANKOWSKA B. 2006. The occurrence of some Lepidoptera pests on different cabbage vegetables. Journal of Plant Protection Research 46(2): 181-190.

JANKOWSKA B. 2008. Effect of French marigold (Tagetes patula nana) plant water extract on the occurrence of pest insects on white cabbage. Progress in Plant Protection 48(2): 724-729. (in Polish)

JANKOWSKA B. 2012. Influence of selected non-chemical ways to protect cruciferous vegetables on harmful and beneficial entomofauna. Zeszyty Naukowe Uniwersytetu Rolniczego w Krakowie, ser. Rozprawy 491(368): 1-131. (in Polish)

JANKowsKa B., PoBOŻNIAK M., WIECH K. 2011. A comparison of insect pest colonization on white cabbage cultivars. Journal of Plant Protection Research 51(2): 157-161.

JANKOWSKA B., WiECH K. 2006. The composition and role of parasitoids in reducing population densities of diamondback moth Plutella xylostella L. on different cabbage vegetables. Journal of Plant Protection Research 46(3): 275-284.

JANKowsKa B., WiLK A. 2011. Effect of Pot Marigold (Calendula officinalis L.) and cypress spurge (Euphorbia cyparissias L.) plant water extracts on the occurrence of pest insects on white cabbage. Folia Horticulturae 23(1): 21-28.

JANKOWSKA B., WOJCIECHOWICZ-ŻYTKO E. 2016. Effect of aqueous extracts of black alder (Alnus glutinosa (LiNNAEUS, 1753) GAERTNER, 1791) and elder (Sambucus nigra LinNAEUS, 1753) on the occurrence of Brevicoryne brassicae LinNAEus, 1758 (Hemiptera, Aphidoidea), its parasitoid Diaeretiella rapae (M'INTOSH, 1855) (Hymenoptera, Ichneumonoidea) and predatory Syrphidae on white cabbage. Polish Journal of Entomology 85(2): 237-246.

KAŁMUK J. 2004. Studies on species composition, biology and effectiveness of parasitoids of harmful butterflies on cruciferous vegetables with particular on diamondback moth Plutella xylostella L. PhD Thesis, University of Agriculture in Kraków, Kraków. (in Polish)

KARIMZADEH J., WRIGHT D.J. 2008. Bottom-up cascading effects in a tritrophic system: interactions between plant quality and host parasitoid immune responses. Ecological Entomology 33(1): $45-52$.

KLOCKE J.A. 1989. Plant compounds as sources and models of insect-control agents. [in:] K. Hosttettmen (ed.). Economic and Medicinal Plant Research. Academic Press, London, $103-144$.

ŁAGOWSKA B. 1981. Ichneumonidae and Braconidae (Hymenoptera) a parasites of diamondback moth - Plutella maculipennis CURT. (Lepidoptera, Plutellidae). Polskie Pismo Entomologiczne 51(2): 355-362.

MiCZULSKI B. 2007. The keys to the initial determination of hymenopterans from the suborder Apocrita (Hymenoptera). Wydawnictwo Akademii Rolniczej w Lublinie, Lublin. (in Polish)

NAwrot J. 1984. Natural products in the protection of plants. Pestycydy 3(4): 1-31. (in Polish)

Palaniswamy P., Wise I. 1994. Effects of neem-based products on number and feeding activity of crucifer flea beetle, Phyllotreta cruciferae (GOEZE) on canola. Journal of Agricultural Entomology 11(1): 49-60.

Pivnick K.A., JaRvis B.J., Slater G.P. 1994. Identification of olfactory cues used in host-plant finding by diamondback moth, Plutella xylostella (Lepidoptera: Plutellidae). Journal of Chemical Ecology 20(7): 1407-1427. 
Pivnick K.A., Jarvis B.J., Slater G.P., Gillot C., Underhill E.W. 1999. Attraction of the Diamondback Moth (Lepidoptera: Plutellidae) to Volatiles of Oriental Mustard: The Influence of Age, Sex, and Prior Exposure to Mates and Host Plants. Environmental Entomology 19(3): 704-709.

Shu-Sheng L., Yue-Hong L., Yin-GUAN L. ZaLUCKi M.P. 2005. Experience induced preference for oviposition repellents derived from a non-host plant by a specialist herbivore. Ecology Letters 8(7): 722-729.

Shu-Sheng L., Yue-Hong L., Yong-Gen L. 2006. Non-host extracts reduce oviposition of Plutella xylostella (Lepidoptera: Plutellidae) and enhance parasitism by its parasitoid Cotesia plutellae (Hymenoptera: Braconidae). Bulletin of Entomological Research 96(4): 373-378.

SZWEJDA J. 2004. Review of pests and their natural enemies actually occurring on cabbages in Poland. Nowości Warzywnicze 39: 97-104. (in Polish)

TABashnik B.E. 1985. Deterrence of Diamondback Moth (Lepidoptera, Plutellidae) Oviposition by Plant Compounds. Environmental Entomology 14(5): 575-578.

TABASHNiK B.E. 1987. Plant secondary compounds as oviposition deterrents for cabbage butterfly, Pieris rapae (Lepidoptera, Pieridae). Journal of Chemical Ecology 13(2): 309-316.

TAhVAnainen J.O., Root R.B. 1972. The influence of vegetational diversity on the population ecology of a specialized herbivore Phyllotreta cruciferae (Coleoptera: Chrysomelidae). Oecologia 10(4): $321-346$

Tóth M., Csonka E., Bakcsa F., Benedek P., Szarukán I., Gomboc S., Toshova T., Subchev M., UjVÁRY I. 2007. Species Spectrum of Flea Beetles (Phyllotreta sp., Coleoptera, Chrysomelidae) Attracted to Allyl Isothiocyanate Baited Traps in Hungary, Slovenia and Bulgaria. Zeitschrift für Naturforschung 62c(9-10): 772-778.

van Loon J.J., BlaAkmer A., Griepink F.C., van Beek T.A., Schoonhoven L.M., Groot A., 1992. Leaf surface compounds from Brassica oleracea (Cruciferae) includes oviposition by Pieris brassicae (Lepidoptera: Pieridae). Chemoecology 3(1): 39-44.

WASINA A. 1987. Use of plants for pest control in orchards and gardens. PWRiL, Warszawa. (in Polish)

WAWRZYNIAK M. 1994. The influence of extracts from selected plants of the borage family (Boraginaceae) on feeding and development of cabbage butterfly (Pieris brassicae L., Lepidoptera, Pieridae). Zeszyty Problemowe Postępów Nauk Rolniczych 414: 265-272. (in Polish)

WAWRZYNIAK M. 1996a. The effect of selected plant extracts on the cabbage butterfly. Habilitation thesis no. 70. Akademia Techniczno-Rolnicza w Bydgoszczy, Bydgoszcz.

WawrzyniaK M. 1996b. The effect of selected plant extracts on the cabbage butterfly, Pieris brassicae L. (Lepidoptera). Polskie Pismo Entomologiczne 65(1): 93-99.

WAWRZYNIAK M. 1996c. Assessment of the effect of selected plant extracts on Pieris brassicae L. (Lepidoptera) and its endoparasite Apanteles glomeratus L. (Hymenoptera). Polskie Pismo Entomologiczne 65(3-4): 327-335.

WAWRZYNiaK M. 1997. Reaction of Pieris brassicae L. and its endoparasitoid Apanteles glomeratus L. to extracts from selected medicinal plants. Biuletyn Warzywniczy XLVII: 63-70. 
WAWRZYNIAK M. 2000. Effect of extracts obtained from some plant of Umbelliferae family on Pieris brassicae L. and its endoparasite Apanteles glomeratus L. Vegetable Crops Research Bulletin 52: $47-54$.

WaWrZYNIAK M. 2009. Effect of extract from Geraniaceae plants on Pieris brassicae L. Journal of Central European Agriculture 10(4): 361-366.

WiECH K, JANKOWSKa B. 1999. Preliminary observations on Diadegma fenestralis a parasitoid of the diamondback moth, Plutella maculipennis. IOBC/WPRS Bulletin 22(5): 145-149.

WiECH K., KAŁMUK J. 2003. Observations on the composition and effectiveness of diamondback moth (Plutella xylostella L.) parasitoids. IOBC/WPRS Bulletin 26(3) :141-147.

WIECH K., KAŁMUK J. 2002.The role of parasitoids in decreasing the number of Diamondback Moth (Plutella xylostella) in horticultural crops. [in:] The BCPC Conference - Pest \& Diseases. Proceedings of an International Conference Held at the Brighton Hilton Metropole Hotel, UK, 1821 November 2002. Volume 1. British Crop Protection Council, Farnham, UK, 329-334.

Received: 30 March 2016

Accepted: 18 May 2016 